January 1997

\title{
Social and cultural factors affecting rates of regular retreatment of mosquito nets with insecticide in Bagamoyo District, Tanzania
}

P.J. Winch

Johns Hopkins University

A.M. Makemba

Bagamoyo Bed Net Project

V.R. Makame

Bagamoyo Bed Net Project

M.S. Mfaume

Bagamoyo Bed Net Project

M.C. Lynch

Johns Hopkins University

See next page for additional authors

Follow this and additional works at: http://ecommons.aku.edu/eastafrica_fhs_mc_pathol Part of the Pathology Commons

\section{Recommended Citation}

Winch, P., Makemba, A., Makame, V., Mfaume, M., Lynch, M., Premji, Z., Minjas, J., Shiff, C. (1997). Social and cultural factors affecting rates of regular retreatment of mosquito nets with insecticide in Bagamoyo District, Tanzania. Tropical Medicine and International Health, 2(8), 760-770.

Available at: http://ecommons.aku.edu/eastafrica_fhs_mc_pathol/92 
Authors

P.J. Winch, A.M. Makemba, V.R. Makame, M.S. Mfaume, M.C. Lynch, Zul Premji, J.N. Minjas, and C.J. Shiff 


\title{
Social and cultural factors affecting rates of regular retreatment of mosquito nets with insecticide in Bagamoyo District, Tanzania
}

\author{
Peter J.Winch', Ahmed M. Makemba²,Viola R. Makame², Mfaume S. Mfaume², Matthew C. Lynch', \\ Zul Premji ${ }^{2,3}$, Japhet N. Minjas ${ }^{2,3}$ and Clive J. Shiff ${ }^{4}$ \\ - Department of International Health, The Johns Hopkins University, School of Hygiene and Public Health, Baltimore, USA \\ $=$ Bagamoyo Bed Net Project, Dar es Salaam, Tanzania \\ ${ }^{3}$ Mubimbili University College of Health Sciences, Dar es Salaam, Tanzania \\ ${ }^{+}$Department of Molecular Microbiology and Immunology, The Johns Hopkins University School of Hygiene and Public Health, \\ Baltimore, USA
}

Summary Insecticide-treated mosquito nets have an impact on mortality and morbidity in young children under controlled conditions. When integrated into larger control programs, there is the danger that rates of regular retreatment of the nets with insecticide will drop, greatly limiting their effectiveness as a public health intervention. In Bagamoyo District, Tanzania, rates of retreatment dropped significantly when payment for the insecticide was introduced. A series of neighbourhood (hamlet) meetings were held in all study villages to discuss people's concerns about the insecticide and ways to increase rates of retreatment. Although changes were made in the procedure for retreatment, rates of retreatment remained lower than expected and showed marked variation within as well as between villages. We then conducted unstructured key informant interviews as well as informal discussions in a village with strong variation between different sectors of the village in rates of retreatment. While logistical problems were most frequently cited as reasons not to bring nets for retreatment, political and social divisions within the community provided a better explanation. This is borne out by the low response to rearrangements in logistics which made retreating the nets significantly easier for households, and the higher response when changes were made in the channels of communication as well as the logistic features. It is clearly more difficult for villagers to appreciate the benefits of the insecticide than those of the nets. Great emphasis needs to be placed on the insecticide and its beneficial effects from the outset for any large-scale programme to be sustainable.

keywords insecticide-treated bednets, re-treatment, Tanzania

correspondence Peter J. Winch, Department of International Health, The Johns Hopkins University, School of Hygiene and Public Health, 6I 5 North Wolfe Street, Baltimore MD 2I205, USA.E-mail: pwinch@welchlink.welch.jhu.edu

\section{Introduction}

In sub-Saharan Africa the cornerstone of malaria control has been promotion of the appropriate use of antimalarial drugs for treatment and prevention. While this remains an essential component of any integrated malaria control effort, the spread of chloroquineresistant Plasmodium falciparum parasites throughout sub-Saharan Africa has stimulated the search for malaria control methods which could complement chemotherapy in an integrated control strategy. One line of investigation has focused on measures which provide 


\section{P. J. Winch et al. Factors affecting retreatment of mosquito nets}

protection from adult mosquitoes, including mosquito nets, eave curtains, window curtains, screening of windows and protective clothing, research which has been summarized by Bermejo \& Veeken (I992), Sexton (I994) and Choi et al. (I995). A general finding has been that treatment of the netting material or fabric with a pyrethroid insecticide greatly increases the protective effect. Recent studies in Ghana and Kenya have provided further evidence that insecticide-treated mosquito nets significantly reduce childhood mortality (Nevill et al. 1996; Binka et al. I996) and there are now calls for operational research into how best to promote the use of insecticide-treated nets on a large scale (Lengeler et al. 1996). A recent study in The Gambia provided evidence that untreated mosquito nets confer some individual protection against malaria, but not as efficiently insecticide-treated mosquito nets

(D’Alessandro et al. I995a). The treated nets were particularly effective in the prevention of infections with high parasitaemia. A previous study in The Gambia found that people sleeping under nets not treated with insecticide do not receive significantly fewer infective bites than those without nets (Lindsay et al I989a).

There are two distinct phases in most malaria control programs involving insecticide-treated mosquito nets. In the initial phase, people acquire insecticide-treated nets for the first time. In areas where people have not previously owned nets, the emphasis in this phase is typically on the nets rather than the insecticide, e.g. on introducing the idea of sleeping under nets to people without prior experience of them, discussing the number and sizes of nets each household needs, and purchase of the nets. In several studies concern over initial acceptance of nets has led to heavy subsidies or outright free distribution of nets in order to ease the postulated resistance to using nets in the community (Sexton I994). In the second phase, people bring their nets in for the first round of retreatment. Here, the emphasis is entirely on the insecticide. While in the initial phase passive acceptance of insecticides suffices, as long as active demand for nets is present, success in the second phase requires active demand for the insecticide on the part of the population, in addition to provision of information about the availability of retreatment, and reasonable access to it at an acceptable cost. The specific issues to be addressed in both phases have been summarized in recent articles by Carnevale \& Coosemans (I995) and Lines (I996).

There are two basic ways in which nets may be treated with insecticide. Wash-resistant insecticide may

Table I Rates of retreatment of nets in six study villages in Bagamoyo District between I99I and I994

\begin{tabular}{|c|c|c|c|c|c|c|c|c|}
\hline \multirow{2}{*}{$\begin{array}{l}\text { Date of } \\
\text { treatment } \\
\text { with } \\
\text { permethrin } \\
\text { Village }\end{array}$} & \multicolumn{4}{|c|}{$\begin{array}{l}\text { Group I } \\
\text { Coastal villages }\end{array}$} & \multicolumn{4}{|c|}{$\begin{array}{l}\text { Group } 2 \\
\text { On main road to Dar es Salaam }\end{array}$} \\
\hline & $\mathrm{Fee}^{\mathrm{a}}$ & Pande & Mlingotini & Kondo & $\mathrm{Fee}^{\mathrm{a}}$ & Mapinga & Kerege & Zinga \\
\hline $\begin{array}{l}\text { May-June } \\
\text { I } 992\end{array}$ & No & $\begin{array}{l}292 / 292 \\
100 \%\end{array}$ & $\begin{array}{l}322 / 322 \\
100 \%\end{array}$ & $\begin{array}{l}226 / 226 \\
100 \%\end{array}$ & N/A & \multicolumn{2}{|c|}{ Nets not yet distributed } & \\
\hline $\begin{array}{l}\text { Nov-Dec } \\
\text { I992 }\end{array}$ & No & $\begin{array}{l}219 / 315 \\
68.3 \%\end{array}$ & $\begin{array}{l}19 \mathrm{I} / 322 \\
59 \cdot 3 \%\end{array}$ & $\begin{array}{l}174 / 226 \\
77.0 \%\end{array}$ & No & $\begin{array}{l}762 / 762 \\
100 \%\end{array}$ & $\begin{array}{l}785 / 785 \\
100 \%\end{array}$ & $\begin{array}{l}593 / 593 \\
100 \%\end{array}$ \\
\hline $\begin{array}{l}\text { May-June } \\
\text { I993 }\end{array}$ & Yes & $\begin{array}{l}136 / 454 \\
30.0 \%\end{array}$ & $\begin{array}{l}83 / 405 \\
20.5 \%\end{array}$ & $\begin{array}{l}187 / 340 \\
55.0 \%\end{array}$ & No & $\begin{array}{l}453 / 762 \\
59 \cdot 4 \%\end{array}$ & $\begin{array}{l}594 / 785 \\
75.6 \%\end{array}$ & $\begin{array}{l}474 / 593 \\
79 \cdot 9 \%\end{array}$ \\
\hline $\begin{array}{l}\text { Nov-Dec } \\
\text { I993 }\end{array}$ & Yes & $\begin{array}{l}259 / 474 \\
54.6 \%\end{array}$ & $\begin{array}{l}256 / 578 \\
44.3 \%\end{array}$ & $\begin{array}{l}286 / 440 \\
65.0 \%\end{array}$ & Yes & $\begin{array}{l}519 / \text { II } 96 \\
43.4 \%\end{array}$ & $\begin{array}{l}48 \mathrm{I} / \mathrm{IIII2} \\
43 \cdot 3 \%\end{array}$ & $\begin{array}{l}449 / \text { IOI3 } \\
44.3 \%\end{array}$ \\
\hline $\begin{array}{l}\text { May-June } \\
\text { I994 }\end{array}$ & Yes & $\begin{array}{l}243 / 323 \\
75.2 \%\end{array}$ & $\begin{array}{l}4 \mathrm{I} 7 / 425 \\
98 . \mathrm{I} \%\end{array}$ & $\begin{array}{l}89 / 359 \\
24.8 \%\end{array}$ & Yes & $\begin{array}{l}484 / 65 \mathrm{I} \\
74 \cdot 3 \%\end{array}$ & $\begin{array}{l}319 / 609 \\
52.4 \%\end{array}$ & $\begin{array}{l}39 \mathrm{I} / 64 \mathrm{I} \\
6 \mathrm{I} .0 \%\end{array}$ \\
\hline $\begin{array}{l}\text { Nov-Dec } \\
\text { I994 }\end{array}$ & Yes & $\begin{array}{l}270 / 350 \\
77 \cdot 1 \%\end{array}$ & $\begin{array}{l}457 / 525 \\
87.0 \%\end{array}$ & $\begin{array}{l}\mathrm{I} 53 / 4 \mathrm{I} 5 \\
36.9 \%\end{array}$ & Yes & $\begin{array}{l}5 \mathrm{II} / 758 \\
67.4 \%\end{array}$ & $\begin{array}{l}355 / 572 \\
62.1 \%\end{array}$ & $\begin{array}{l}423 / 666 \\
63.5 \%\end{array}$ \\
\hline
\end{tabular}

${ }^{\mathrm{a} F e e}$ charged for insecticide treatment. 
P. J. Winch et al. Factors affecting retreatment of mosquito nets

be incorporated directly into the fibres, in which case retreatment may not be necessary for two years or more, although such nets will cost significantly more than ordinary netting (Curtis et al. I996). If the insecticide is not incorporated into the fibers, nets need to be retreated with insecticide every six to I 2 months depending on the insecticide used and the local pattern of malaria transmission. Regardless of whether the insecticide is incorporated into the fibres or the netting requires periodic treatment, it will be essential to understand perceptions of the insecticide. Unless people appreciate the benefits of the insecticide it is unlikely they will invest in this extra cost. For netting requiring retreatment, people must not only be willing to pay for the insecticide, but also invest time and effort in bringing their net to a central location for retreatment or purchasing the insecticide and retreating the netting on their own.

We present results of research into factors which affect demand for and acceptance of retreatment of mosquito nets with the insecticide permethrin in a malaria control project conducted in Bagamoyo District, Tanzania. One of the aims of the project was the development of a sustainable system for distributing and promoting the use of impregnated mosquito nets at the village level (Makemba et al. 1995). Although the initial phase of distribution enjoyed considerable success in the I3 project villages, during the first reimpregnation exercises in three coastal villages (Group I) in November and December 1992 coverage rates fell far short of desired levels, and fell further when cost recovery was instituted in May-June I993 (Table I). A similar phenomenon was reported in a national mosquito net programme in The Gambia: when people had to pay for the insecticde, rates of retreatment fell and child mortality rates returned to preintervention levels (D’Alessandro et al. I995b).

\section{Materials and methods}

Study site

Our research was conducted as part of a larger study on insecticide-treated nets, the Bagamoyo Bed Net Project (Makemba et al. I995; Premji et al. 1995) in I3 villages in Bagamoyo District on the coastal plain of Tanzania, $50 \mathrm{~km}$ north of the capital Dar-es-Salaam. Nets were introduced in 3 villages at a time at 6-month intervals.
We focus on the experience of the first 6 villages who received treated nets for the first time in May-June I992 (Group I) and November-December I992 (Group 2) as shown in Table I. The predominant ethnic groups are the Zaramo, Kwere and Swahili, although 30 other ethnic groups are represented in smaller numbers. Swahili is the principal language used, although Zaramo is also common. The population of approximately $2 \mathrm{I} 000$ is primarily Muslim. In a survey of 56I households conducted prior to net sales and distribution by the project in I99I, 52I (9I.9\%) of the households owned no net at all, $36(6.3 \%)$ had one net and Io (I.8\%) owned 2 or more. Treatment of netting material with insecticides had never been practised in the study area before the start of the project.

\section{Qualitative research}

The I 3 study villages were divided into 4 groups for purposes of implementation of the mosquito net intervention (Makemba et al. I995). In the first 3 villages (located on the coast), nets were distributed for the first time in June I992; the nets were retreated with permethrin free of charge in December 1992 and for a fee of 50 Tanzanian Shillings (US\$ O.I5) per net in June I993 (Table I). The rates of retreatment in the three coastal villages were $68.3 \%, 59.3 \%$ and $77.0 \%$ in December I 992 and dropped to $30.0 \%, 20.5 \%$ and $55.0 \%$, respectively, in June I993. Sixty semistructured open-ended interviews were conducted in September and December 1993 in these 3 coastal villages: 20 respondents listed all the types of dawa they knew (a local term referring to both insecticide and pharmaceuticals), and all respondents discussed benefits of treating nets with the insecticide, side-effects of the insecticide and barriers to bringing nets in for retreatment. Members of village mosquito net committees and of village governments were also interviewed. As a result of these interviews, a series of neighbourhood (hamlet) meetings were held in all study villages to discuss peoples' concerns about the insecticide and ways to increase rates of retreatment. Changes were made in the procedure for retreatment to make it more convenient, but rates of retreatment were still lower than expected and showed marked variation within as well as between villages. In February I994, 4 members of the social science research team spent one week in a village to try to clarify this variation. They 
P. J. Winch et al. Factors affecting retreatment of mosquito nets

carried out participant observation of sleeping patterns, 20 unstructured key informant-type interviews and informal discussions with villagers during the evenings. Notes from semistructured and unstructured interviews, hamlet meetings and participant observation were expanded, entered into word processing files and coded.

\section{Results}

\section{Perceptions of the insecticide}

Whenever villagers referred to the insecticide, the Swahili word invariably used was dawa. While dawa is the local term used to translate the English word insecticide, relying on the word insecticide as a translation can be misleading, as it does not capture all that is meant by dawa. The meaning of dawa that emerged from the interviews is very broad and encompasses almost any substance that produces noticeable effects, including drugs obtained at the clinic or pharmacy, treatments prescribed by traditional practitioners, insecticides used in agriculture, mosquito coils, poisons for controlling rodents, and chemicals in general. Twenty respondents were asked to list all the types of dawa they knew. Those that were mentioned 3 or more times included the chemical fungicide used to treat the cashew trees (dawa ya korosho, also referred to as sulfa) (I 8 mentions), chloroquine or 'bitter medicine' (9), aspirin (8), Aspro (3), Panadol (3) and Cafenol (3), the latter three terms being proprietary names of widely available pain medications. Respondents named types of dawa according to what they are used for, e.g. dawa ya homa (dawa for fever = chloroquine), dawa ya kichwa (dawa for the head/headache), or how they are used or applied, e.g. dawa ya kupulizia (dawa to be sprayed = aerosol insecticide spray), dawa ya kuchoma (dawa to be burnt $=$ mosquito coils). Another distinction made was between dawa used for human consumption and dawa used to kill insects and rodents. This distinction is, however, less rigid than the distinction between medicine and pesticide in English. For example, some respondents reported that fungicide used on cashew trees is sometimes used to treat scabies and head lice.

All of the 60 respondents in the initial set of interviews felt that the insecticide 'works', or has beneficial effects. Several lines of evidence were used to support this contention. Some people stated that mosquitoes die after touching the net, or that there are dead insects under the bed after laying the net on the bed to dry. Other arthropods, such as bedbugs and cockroaches were also said to be affected, as has been reported elsewhere (Charlwood \& Dagaro I989; Lindsay et al. I989b). In some cases these observations discouraged retreatment, because respondents felt that as long as the net was still killing insects there was no reason to have it retreated. Respondents also stated that overall mosquito densities, as well as fevers, had diminished since the introduction of the nets. When describing the impact of the insecticide on insects, respondents used words such as poison (sumu), danger (hatari), harsh/strong (kali), and kill/death, as seen as statements such as 'It's strong dawa, it even kills cockroaches.'

We had expected respondents to draw a sharp distinction between insecticides and agricultural chemicals not intended for human consumption, and medications used to treat people. In fact, a more salient and fundamental distinction made was between local/indigenous/traditional types of dawa (dawa za kienyeji, dawa za kiswahili) and European/foreign/ modern types of dawa (dawa za kizungu). The former includes not only the full range of treatments prescribed by traditional practitioners, but also plants burned in order to drive off mosquitoes or used for other nonmedical purposes. The latter includes factoryproduced prescription drugs, insecticides and poisons.

The permethrin insecticide used in this project is either referred to as dawa with no qualification, or as dawa ya chandalua (dawa for the net). It is seen as a foreign/modern type of dawa, one that is far more effective than traditional dawa such as vumbasi, a type of herb which is burnt in order to drive off mosquitoes. It is one of three types of modern dawa used for protection from mosquitoes, the others being mosquito coils and aerosol insecticides. To some extent experience with other modern dawa was transferred to the insecticide. Some respondents stated that for any modern dawa you need to follow the instructions carefully to avoid problems. Just as you should not take four pills if the doctor says to take two, so too you need to use the right amount of insecticide.

\section{Reasons for not retreating nets with insecticide}

In the initial series of 60 semistructured interviews and meetings with members of village mosquito net committees and local leaders in the 3 coastal villages, 4 
P. J. Winch et al. Factors affecting retreatment of mosquito nets

principal reasons were cited for the low rates of retreatment of nets: the fee charged for retreatment; inconvenience of the retreatment; many nets were not in use; concerns about toxicity of the insecticide. The first 3 reasons were generalized problems in all villages, while concern about toxicity was a more focal problem strongly influenced by local leaders.

Of the 60 people interviewed, 20 had not brought their nets to be retreated during the most recent retreatment exercise, and I 5 of these 20 cited the fee as the reason, Io cited the inconvenience associated with retreating the net. The main reason people stated why they could not pay the fee was that they had not had sufficient advance notice. Information about payment of the fee was only disseminated in the month before the retreatment exercise. Villagers asserted that they needed 3 or more months advance notice so that could put aside money for it. Others objected to the change in policy: retreatment had been free during the first round (November-December I992), then a fee was instituted (May-June I993).

There was this big problem of the 50 Shilling fee for each net. We are resistant to paying for this kind of thing. Something that starts off free, then later there is a change and you have to pay money, people refuse to pay.

People with large families had often purchased 5 or more nets. Although the fee for one net was reasonable, they felt the overall cost was too high. At the same time, they felt uncomfortable bringing in one or two for retreatment and leaving the others untreated. People who disapproved of the project charging for retreatment of nets sometimes cited the fact that other types of modern dawa such as agricultural chemicals and medicines are given away free by the government. Although many could afford to pay for retreatment, they objected to the principle of paying for modern dawa. Finally, some people objected to paying for the dawa while the foreigners (wazungu) were still around: why couldn' t they pay for it? The retreatment exercise was carried out on one day only, and only at one central location in each village. Fishermen found this very inconvenient. If it happened to be a good day for fishing, they would be out on the water at the time of retreatment. Others were travelling outside the village or working in their fields located at a considerable distance from the centre of the village.
Respondents did not even consider retreating their net with insecticide if the net was not currently in use. Some nets were being stored in case guests came, and had never been taken out of the package. During hot and dry periods of the year (e.g. December I993), some people stated that the low mosquito densities did not warrant their use and, furthermore, that it was too hot to use them. In some villages, located far from major mosquito larval habitats such as rice fields, densities are never very high. Five people stated that they had their net first impregnated with insecticide in June, when mosquito densities are already past their peak, and had still not used the net at the time of retreatment in December, reasoning that the only time of the year when net usage is warranted is during the long rains. They thought that there was no reason to have an unused net retreated. People not only did not want to retreat unused nets, but some were also hesitant to bring in heavily used and dirty nets. No one stated this directly, so it is difficult to quantify its importance, rather they stated that 'other people' feel it is shameful to bring in a dirty net. Villagers had been told to avoid washing their nets until the time came for the net to be retreated. The unintended consequence of this may be that people avoid bringing in their net for retreatment.

\section{Concerns about toxicity}

The meaning of dawa in Swahili includes not only drugs and insecticides, but also poisons and charms, the latter meaning emerging from other research in the area with traditional healers (Makemba et al. 1996). Efficacy and toxicity were felt to go hand in hand: the greater the demonstrable effects of any dawa, the greater the potential for toxicity. Some respondents considered any dawa to potentially be poisonous (sumu), as illustrated in this quote

Many people think that any kind of dawa is poison, so for example, they spread out their nets outside in the shade (to dry after treatment with the insecticide, although they were instructed to spread them out inside on their bed) because they think the dawa is poison.

Certain aspects of the way treatment of the nets with insecticide is carried out amplify concerns about toxicity. Villagers who were treating the nets had to wear gloves, and people were told not to touch the insecticide, and to burn or bury the plastic bag that they used to carry the nets home. One respondent said 'we were worried when we were told to throw away the plastic bag that we put 


\section{P. J. Winch et al. Factors affecting retreatment of mosquito nets}

the net into, we villagers feel that it's poison, that dawa.' The instruction to bury the plastic bag particularly heightened concern. Some people experienced side-effects the first few days after retreatment, such as runny nose and nasal irritation, but this did not appear to be a major reason to not retreat nets.

Concerns about toxicity were greatest for children. Some people felt that if the dawa was so toxic for insects and other small animals, it would also be toxic for children. Another reason that children were said to be particularly vulnerable to the toxic effects of the insecticide was that they may chew or suck on the netting while asleep. The toxic effects of the dawa on children were a particular concern for women. In some villages there was almost no detectable concern about the toxic effects of the insecticide, while in others it was widespread and generalized. In a section of one coastal village, the child of the Medical Assistant had experienced skin itching and sneezing which he attributed to the child sleeping under a net, and this individual had spread the news that the dawa was toxic for children. This contributed to a very low rate of retreatment $(29 \%)$ compared to neighbouring villages.

\section{Measures taken to increase rates of retreatment}

Although people cited the fee as the major barrier, retreatment was already being offered at a subsidized rate. Rather than increase the level of subsidy, the project planned to decrease it over time. Efforts were therefore made to make retreatment more accessible and to increase demand for the insecticide. Accessibility was

Table 2 Social and political factors potentially affecting rates of retreatment of nets with insecticide in Mapinga village, Bagamoyo District, 1994

\begin{tabular}{|c|c|c|c|c|}
\hline Hamlet & I & 2 & 3 & 4 \\
\hline Rate of net retreatment in June I994 & $55 \%$ & $77 \%$ & $92 \%$ & $77 \%$ \\
\hline Location of hamlet & $\begin{array}{l}\text { On main road } \\
\text { from } \\
\text { Bagamoyo to } \\
\text { Dar es Salaam }\end{array}$ & $\begin{array}{l}\text { West of the } \\
\text { main road ad- } \\
\text { jacent to the } \\
\text { Forest } \\
\text { Reserve }\end{array}$ & $\begin{array}{l}\text { East of the } \\
\text { main road, } \\
\text { close to the } \\
\text { Indian Ocean }\end{array}$ & $\begin{array}{l}\text { East of } \\
\text { main road, } \\
\text { on Indian } \\
\text { Ocean }\end{array}$ \\
\hline Age of the hamlet & $\begin{array}{l}\text { Original } \\
\text { village, >IOO } \\
\text { years }\end{array}$ & \multicolumn{2}{|c|}{$\begin{array}{l}\text { New settlements established and populated } \\
\text { since I } 970\end{array}$} & \\
\hline $\begin{array}{l}\text { On-going arrival of new } \\
\text { settlers }\end{array}$ & Very little & Some & Many & Some \\
\hline Origin of the population & $\begin{array}{l}\text { Local groups, } \\
\text { especially } \\
\text { Zaramo }\end{array}$ & $\begin{array}{l}\text { Mixture, prima } \\
\text { southern and ce } \\
\text { Makonde, Ngo }\end{array}$ & $\begin{array}{l}\text { local groups from } \\
\text { nzania including } \\
\text { Sukuma. }\end{array}$ & \\
\hline Seasonal work/migration & Uncommon & Common & Common & $\begin{array}{l}\text { Very } \\
\text { common }\end{array}$ \\
\hline Production of charcoal & Uncommon & Common & Very common & $\begin{array}{l}\text { Very } \\
\text { common }\end{array}$ \\
\hline $\begin{array}{l}\text { Harvesting salt from sea } \\
\text { water }\end{array}$ & Uncommon & Uncommon & Common & $\begin{array}{l}\text { Very } \\
\text { common }\end{array}$ \\
\hline Agricultural income & $\begin{array}{l}\text { Coconuts, } \\
\text { mangoes, } \\
\text { cashews }\end{array}$ & $\begin{array}{l}\text { Casual farm } \\
\text { labour }\end{array}$ & $\begin{array}{l}\text { Cashews, } \\
\text { casual farm } \\
\text { labour }\end{array}$ & $\begin{array}{l}\text { Casual } \\
\text { farm labour }\end{array}$ \\
\hline $\begin{array}{l}\text { Traditional organization } \\
\text { and leadership }\end{array}$ & Weak & Strong & Very strong & Strong \\
\hline $\begin{array}{l}\text { Sharing of } \\
\text { money/informal credit }\end{array}$ & Uncommon & Common & Common & Common \\
\hline Cash availability & High & Very low & Low & Low \\
\hline Priority given to health & Low & High & High & High \\
\hline
\end{tabular}




\section{P. J. Winch et al. Factors affecting retreatment of mosquito nets}

improved by the operation of 3 or more retreatment stations in different sectors of each village; retreatment was made available all day for three days, instead of one day only, and announcements were made with a portable megaphone for people to bring in their nets. Demand for retreatment was stimulated through meetings at the neighbourhood or hamlet level (kitongoji) to stress the importance of retreatment and to answer any questions people might have. Previously only village-wide meetings had been held, and these were found to primarily reach men living at the centre of the village. Topics covered included:

- mosquitoes are a problem and can cause disease even if they are few in number (Winch et al. 1994)

- malaria has serious consequences beyond fever, such as anaemia and complications of pregnancy (Winch et al. 1996)

- the insecticide does not cause harm to children who sleep under treated nets; the dawa only works for 6 months

- the relative cost of retreating nets every 6 months vs. purchasing mosquito coils on a regular basis.

Case study of Mapinga village

As a result of these procedural changes, we expected rates of retreatment in the second group of 3 villages to be much higher than they had been in the first group of 3 coastal villages. But the retreatment rates in this second group in December 1993 were only $43.4 \%, 43.3 \%$ and $44.3 \%$ (Table I), a disappointing result. The low overall rates masked the fact that some sectors (hamlets) of the villages had high rates, while others had low rates. The sectors with the lowest rates tended to be older, longsettled, central parts of the village whose residents were comprised mostly of local (coastal) ethnic groups. The sectors with the highest rates tended to be newer, recently settled, peripheral parts of the village whose residents were comprised mostly of immigrants from southern and central Tanzania. According to Table 2, in hamlets 2, 3 and 4 of Mapinga village people have less access to cash and more work as day-labourers. Heavy alcohol use is also more common among some groups. Finally, hamlets 2, 3 and 4 are farther from the centre of the village, so the residents would be expected to have less access to information about nets and insecticide, in addition to having to walk farther to bring in their nets for retreatment. It would therefore be expected that Hamlet I would have a high rate of retreatment, while Hamlets 2, 3 and 4 would have low rates. In fact the opposite pattern is found, as illustrated in Table 2 with data from the June 1994 round of retreatment of nets. To investigate this situation further, 4 members of the social science research team each spent one week in a different sector of Mapinga village where rates of retreatment were most discrepant (Table 2). Most of the variation in retreatment rates were found to be attributable to economic and political factors.

\section{Economic factors affecting rates of retreatment}

Some people, such as fishermen and government employees (teachers and agricultural extension agents), reported little seasonal variation in access to cash. Others reported strong seasonal variations in ability to pay for retreatment, as shown in Table 3. Owners of small plots of land said they had the most cash income from November to February when cash crops such as cashew nuts and mangoes are harvested. From June to August during the rice harvest they have some cash income, but it is limited as much of the rice is for their own use. Before harvests they have little income. People working as day-labourers (kibarua) in agriculture only have cash when there is agricultural work. During the

Table 3 Seasonal variation in cash income in three occupational categories, Mapinga village I994

\begin{tabular}{|c|c|c|c|}
\hline Group & $\begin{array}{l}\text { Owners of small } \\
\text { plots of land }\end{array}$ & $\begin{array}{l}\text { Day-labourers: } \\
\text { Agriculture }\end{array}$ & $\begin{array}{l}\text { Day-labourers: } \\
\text { Salt mines }\end{array}$ \\
\hline $\begin{array}{l}\text { November to } \\
\text { February (hot } \& \text { dry } \\
\text { with intermittent rain) }\end{array}$ & $\begin{array}{l}\text { Yes_-sale of cash crops } \\
\text { (cashews, mangoes) }\end{array}$ & No-unless it rains & Yes_-unless it rains \\
\hline March to May (heavy rain) & $\mathrm{No}$-waiting for rice harvest & Yes-if it rains & No-unless it doesn't rain \\
\hline June to August (rice harvest) & Yes-after rice harvest & Yes-until harvest ends & Yes-once rain stops \\
\hline
\end{tabular}




\section{P. J. Winch et al. Factors affecting retreatment of mosquito nets}

hot and dry season many leave to search for work in Dar es Salaam. Those who work in the salt mines on the Indian Ocean have the opposite pattern: they are out of work when it rains. In addition, day-labourers of all types tend to get paid on the weekend when land owners visit from Dar-es-Salaam. By mid-week they have little or no cash left.

Some women cited lack of control over the household budget as a reason for not retreating their nets. They stated that a wife may be willing to retreat the nets but does not have the money, while the husband may not assign high priority to treatment of the nets. Women involved in small businesses such as frying fish and selling vegetables in the market often have to pay for all household expenses. They need all the money for food and have none left for treatment of nets.

Throughout most of the study area, the consumption of alcoholic beverages is uncommon. Small settlements exist, however, that are composed to a large extent of young men who have migrated, primarily from southern Tanzania. They work, usually as day-labourers, in fishing, farming or extraction of salt from sea water. In these settlements we found both high levels of alcohol intake and low levels of net usage and retreatment. Some of the men interviewed explained that once they are drunk, they don't feel mosquito bites. They don't know when they have been bitten by mosquitoes, and say that malaria and other fevers are not a problem for them, many having gone without an episode of fever for a long time. Inebriation also lessens perceived vulnerability to disease in general among some men. Men interviewed in local bars said that they were strong, healthy and could not be attacked by other diseases. Other effects of inebriation observed were that these men go to bed very late, may not sleep in their normal bed and may not use a net even if they have one. High levels of alcohol use also have an economic impact. Based on observations of project staff, some young men spend most of their income on locally brewed beer, leaving little money for nets and insecticide or even for food.

\section{Political factors affecting rates of retreatment}

The second phase of interviews in February 1994 focused on understanding the variations in rates of retreatment within the one village chosen as a case study. This village is divided into 2 major groups, a pattern also observed in neighbouring villages. One group is dominated by the Zaramo and consists of people from local ethnic groups living at the centre of the village and speaking local languages. The other group are referred to as the 'guests' (wageni) by the first group. They have migrated to the coast from the interior of Tanzania, especially the southern highlands bordering on Malawi and Mozambique, and are predominantly Christian. They live on the periphery of the village where land is more plentiful, cultivate larger plots of land, grow a greater variety of crops including maize, and insist that their children attend public school. Many, but far from all, in the first group stated either directly or indirectly that their power and way of life are being eroded by the influx of government employees, migrants and externally funded projects into Bagamoyo District. Those in the second group, the 'guests', had a different point of view. They considered treatment of diseases with modern medicines and treatment of nets with modern dawa a positive step, one of a number of modern behaviours and technologies in which they are eager to invest. They have moved into the area to improve their lives. When asked his reaction to nets, one respondent stated 'I see them as part of development, so I'm not amazed by them ... these changes are necessary'.

We found that ro-cell leaders (representatives of Io houses or balozi) are highly aware of the rates of retreatment achieved in their neighbourhood. High rates of retreatment are interpreted as a sign of support for ro-cell leaders, as well as for the village mosquito net committees and the village government. Factionalism in the centre of villages apparently results in some people not bringing in their nets for retreatment. Conversely, the social cohesion and strong leadership found in peripheral areas of the villages favours higher rates of retreatment. Leaders in the 3 peripheral hamlets $(2,3$ and 4 in Table I) reiterated their support of the project in interviews, and sent strong messages to their fellow villagers to buy nets and bring them in for retreatment. The research team also noted that there is more trust which allows people to borrow money to have their nets retreated and pay it back later.

\section{Discussion}

The experience in Bagamoyo indicates that even in a population unused to sleeping under mosquito nets, there was little resistance to purchasing and sleeping 


\section{P. J. Winch et al. Factors affecting retreatment of mosquito nets}

under nets when they were sold for the equivalent of $\mathrm{US}_{4}-5$ (Close to their actual value, but about half the price of nets in shops). The initial subsidization of the nets and insecticide may have had an overall detrimental effect with respect to acceptance of the insecticide. Villagers accepted the nets enthusiastically, but reacted negatively to the inevitable reduction of the subsidies. This is consistent with experience in The Gambia (D'Alessandro et al. I995b) and provides an important lesson for future projects which seek to institutionalize community-based mosquito net interventions, as discussed also by Lines (I996). A more sustainable approach might be for the project to emphasize the insecticide from the outset, with the net presented as simply a vehicle upon which the insecticide is hung.

The interviews demonstrate that while logistical problems were the common explanation for failure to bring nets for retreatment, political or social divisions within the community needed to be taken into account to explain variation in rates of retreatment within villages. This was borne out by the low response to rearrangements in logistics which made retreating the nets significantly easier for households. In subsequent rounds of retreatment, efforts were made to address these political factors, e.g. by having all different groups in the village represented on the village mosquito net committee. In promoting net sales and retreatment, the source of information or channel of communication was changed according to the group being addressed, for example if one group had low rates of reimpregnation, another person from the same group was sent to speak to them. More politically neutral channels of communication were used:, e.g. elementary schools instead of the village government. Even with these changes, rates of retreatment did not increase to an acceptable level in all villages, as shown in Table I. While the rates of retreatment and the absolute numbers of nets treated increased between May I993 and December I994 in 2 Group I villages (Pande and Mlingotini), levels in the third Group I village remained low. In the Group 2 villages, many nets moved out of the village due to people working seasonally in Dar-esSalaam and Bagamoyo town as well as sale of nets, both of which are influenced by the location of the Group 2 villages on the Dar es Salaam-Bagamoyo road. The increasing rates of retreatment from November 1993 to December 1994 are therefore due in part to a shrinking denominator.
Ensuring the greatest possible ease of retreating the nets contributed to maintaining and/or increasing the coverage rates in these villages. Establishing substations for treatment closer to people's homes was an important change in an area in which the most common transportation mode is walking. Extending the length of time the dip was available in each station from I to 3 days was also effective in improving access. Timing the retreatment opportunity to the seasonal cash flow of local residents is much more complex than at first glance, as each occupational group has its own 'best' time for cash availability, and each neighbourhood or kitongoji may contain a variety of occupational groups. The villagers' observation that up to 3 months prior notice is needed is probably close to the truth.

It is not clear how much of the resistance to paying for insecticide is due to financial hardship and how much to resentment over paying for a service that was previously free of charge. The amount being charged for the retreatment ( 50 shillings) was in fact minimal and reflected a continuing partial subsidy. This amount at that time was approximately the cost of a single bottle of a soft drink, an item commonly available in village shops. For families with multiple nets, and for the poorest families in the village, it is possible that the combined charge could present a significant drain on available cash supplies. It is difficult to believe that the absolute amount presents a major barrier for the majority of households, however.

Nichter \& Vuckovic (I994) provide a comprehensive list of research issues significant in the anthropology of use of pharmaceuticals. Many of the same issues are pertinent to research into factors affecting compliance with the retreatment of mosquito nets with insecticide. For example, the distinction between local and foreign drugs/chemicals found in this study has been noted in other studies on the anthropology of pharmaceuticals. Hunte \& Sultana (I992), for example, found that people distinguished between local medicines (deysi dewa) and modern medicines (doctori dewa or engrayzi dewa) in a study in Baluchistan and Lambert (I996) notes a similar local-foreign distinction (desidvai vs. angreji dvai) in rural north India. Other comparable issues include the benefits and side-effects of the treatment, comparisons that consumers make in cost and toxicity, and concerns that people have that dosage and timing must be correct if the effect is to be right. Care needs to be taken in presenting the benefits and side-effects of the insecticide 


\section{P. J. Winch et al. Factors affecting retreatment of mosquito nets}

to the community. Local perceptions of the insecticide may be influenced not only by properties of the insecticide itself, but also by the local term used to translate insecticide, and the range of meanings that this term has in everyday use.

Key benefits of the insecticide that might be stressed include its effect on mosquitoes, collateral effects on bed bugs and cockroaches (Charlwood \& Dagaro I989; Lindsay et al. I989b) or protection from malaria. Emphasis solely on protection from mosquitoes may lead people to not sleep under nets when mosquito densities are low (Winch et al. I994). Emphasis on protection from bed bugs and cockroaches may not motivate people who do not consider these to be a problem and may lead to lower acceptance of the insecticide if these nontarget arthropods develop resistance to the insecticide. Low acceptance of intradomiciliary application of insecticide in malaria eradication programs was reported when resurgent insecticide-resistant bed bug populations appeared (Rafatjah I97I). Finally, differences in local terminology and perceptions of malaria may mean that protection from malaria also fails to motivate people to bring in their nets for retreatment. Systematic formative research into the perceived benefits of insecticide retreatment should therefore be included in any programme that seeks to promote high and sustainable levels of retreatment.

\section{References}

Bermejo A \& Veeken H (I992) Insecticide-impregnated bed nets for malaria control: a review of the field trials. Bulletin of the World Health Organization 70, 293-296.

Binka FN, Kubaje A, Adjuik M et al. (I996) Impact of permethrin-impregnated bednets on child mortality in Kassena-Nankana district, Ghana: a randomized controlled trial. Tropical Medicine and International Health I, I47-I 54.

Carnevale P \& Coosemans M (1995) Some operational aspects of the use of personal protection methods against malaria at individual and community level. Annales de la Société Belge de Medécine Tropicale 75, 8I-I03.

Charlwood JD \& Dagaro H (I989) Collateral effects of bednets impregnated with permethrin in controlling bed bugs (Cimicidae) in Papua New Guinea. Transactions of the Royal Society of Tropical Medicine and Hygiene 83, 26I.

Choi HW, Breman JG, Teutsch SM et al. (I995) The effectiveness of insecticide-impregnated bed nets in reducing cases of malaria infection: a meta-analysis of published results. American Journal of Tropical Medicine and Hygiene 52, $377-382$.
Curtis CF, Myamba J \& Wilkes TJ (I996) Comparison of different insecticides and fabrics for anti-mosquito bednets and curtains. Medical and Veterinary Entomology Iо, I-I I.

D'Alessandro U, Olaleye BO, McGuire W et al. (1995a) A comparison of the efficacy of insecticide-treated and untreated bed nets in preventing malaria in Gambian children. Transactions of the Royal Society of Tropical Medicine \& Hygiene. 89, 596-598.

D’Alessandro U, Olaleye BO, McGuire W et al. (1995b) Mortality and morbidity from malaria in Gambian children after introduction of an impregnated bednet programme. Lancet 345, 479-483.

Hunte PA \& Sultana F (1992) Health-seeking behavior and the meaning of medications in Balochistan, Pakistan. Social Science and Medicine 34, $1385-\mathrm{I} 397$.

Lambert H (I996) Popular therapeutics and medical preferences in rural north India. Lancet 348, I706-I709.

Lengeler C, Lines JD, Cattani J et al. (I996) Promoting operational research on insecticide-treated netting: a joint TDR/IDRC initiative and call for research proposals. Tropical Medicine and International Health I, 273-276.

Lindsay SW, Shenton FC, Snow RW \& Greenwood BM (I989a) Responses of Anopheles gambiae complex mosquitoes to the use of untreated bednets in The Gambia. Medical and Veterinary Entomology 3, 253-262.

Lindsay SW, Snow RW, Armstrong JRM \& Greenwood BM (I989b) Permethrin-impregnated bed nets (mosquito nets) reduce nuisance arthropods in Gambian houses. Medical and Veterinary Entomology 3, 377-383.

Lines J (1996) Mosquito nets and insecticides for net treatment: a discussion of existing and potential distribution systems in Africa. Tropical Medicine and International Health I, 6I6-632.

Makemba AM, Winch PJ, Kamazima SR et al. (1995) Implementation of a community-based system for the sale, distribution and insecticide impregnation of mosquito nets in Bagamoyo District, Tanzania. Health Policy and Planning Io, $50-59$.

Makemba AM, Winch PJ, Makame VM et al. (I996) Treatment practices for degedege, a locally-recognized febrile illness, and implications for strategies to decrease mortality from severe malaria in Bagamoyo District, Tanzania. Tropical Medicine and International Health I, 305-3I3.

Nevill CG, Some ES, Mung'ala VO et al. (1996) Insecticidetreated bednets reduce mortality and severe morbidity from malaria among children on the Kenyan coast. Tropical Medicine and International Health I, I39-I46.

Nichter M \& Vuckovic N (I994) Agenda for an anthropology of pharmaceutical practice. Social Science and Medicine 39, I509-I525.

Premji Z, Lubega P, Hamisi Y et al. (1995) Changes in malaria associated morbidity in children using insecticide treated 
P. J. Winch et al. Factors affecting retreatment of mosquito nets

mosquito nets in the Bagamoyo District of Coastal Tanzania. Tropical Medicine and Parasitology 46, I47-I53.

Rafatjah H (I97I) The problems of resurgent bed-bug infestation in malaria eradication programmes. Journal of Tropical Medicine and Hygiene 74, 53-56.

Sexton JD (I994) Impregnated bed nets for malaria control: biological success and social responsibility. American

Journal of Tropical Medicine and Hygiene 5I (Supplement), $72-8 \mathrm{I}$.
Winch PJ, Makemba AM, Kamazima SR et al. (I996) Local terminology for febrile illnesses in Bagamoyo District,

Tanzania and its impact on the design of a community-based malaria control programme. Social Science and Medicine 42, I057-1067.

Winch PJ, Makemba AM, Kamazima SR, Lwihula GK, Lubega P, Minjas JN et al. (I994) Seasonal variation in the perceived risk of malaria: implications for the promotion of insecticideimpregnated bed nets. Social Science and Medicine 39, 63-75. 